\title{
Potential producers of biogenic magnetic nanoparticles among disease-producing microorganisms of the brain
}

\author{
S.V.Gorobets, O.Yu.Gorobets, Y.A.Darmenko \\ National Technical University of Ukraine "Igor Sikorsky Kyiv Polytechnic \\ Institute", 37 Pereniohy Ave., 03156 Kyiv, Ukraine
}

Received February 2, 2017

\begin{abstract}
In this paper, microorganisms-causative agents of brain disease have the potential to produce biogenic magnetic nanoparticles (BMN), which can accumulate in the human brain in addition to BMN, which are biomineralized in the human brain. The BMN of these microorganisms can attract particular interest for the manufacture of magnetic nanoparticles as functional materials of a wide range of applications such as nanoelectronics, targeted delivery of drugs and a contrast agent for magnetic resonance imaging.

Keywords: biogenic magnetic nanoparticles, pathogenic microorganisms, meningitis.
\end{abstract}

\begin{abstract}
Установлена потенциальная восприимчивость микроорганизмов-возбудителей заболевания мозга к продукции биогенных магнитных наночастиц (БМН), которые могут накапливаться в мозге человека дополнительно к БМН, которые биоминерализуются в мозге человека. БМН этих микроорганизмов могут представлять особый интерес для изготовления магнитных наночастиц как функциональных материалов широкого спектра использования, например, для наноэлектроники, при целевой доставке лекарств, как контрастный агент для магнитно-резонансной томографии.
\end{abstract}

Потенційні продуценти біогенних магнітних наночастинок серед мікроорганізмів збудників захворювань мозку. С.В.Горобець, О.Ю.Горобець, С.А.Дарменко.

Встановлено потенційна чутливість мікроорганізмів-збудників захворювання мозку до продукції біогенних магнітних наночастинок (БМН), які можуть накопичуватися у мозку людини додатково до БМН, які біомінералізуються у мозку людини. БМН цих мікроорганізмів можуть становити окремий інтерес для виготовлення магнітних наночастинок як функціональних матеріалів широкого спектру використання, наприклад, для наноелектроніки, при цільовій доставці ліків, як контрастний агент для магнітнорезонансної томографії.

\section{Introduction}

For several decades the interest in drug delivery systems using magnetic nanoparticles is increased. On today, the topical issues are connected with the presence of biogenic magnetic nanoparticles (BMNs) in human organs and tissues that should be considered in the design of such systems.

BMNs are revealed in many organs of the human's body. Normally BMNs locate in heart, liver, spleen [1] adrenal glands [2], ethmoid bone [3] and brain [4-7]. During inflammatory processes and pathologies, such as atherosclerotic plaques [8], the neurodegenerative (Alzheimer's, Parkinson's, Huntington's [9]) and cancer the number of BMN is considerably larger than the normal range [5].

It's important to understand how magnetic nanoparticles of artificial and natural origin that ingested as part of magnetically labeled drugs or as part of symbioses, pathogens and opportunistic bacteria may 
interact with BMN that are located in human's organs and tissues [10]. Also the work [11] showed that the use of magnetic resonance imaging method (MRI) can be dangerous to the human brain with the accumulation of BMN with age [12].

Since the discovery of BMN in living organisms the BMNs have been considered as a functional material that provides magnetotaxis in bacteria [13] and magnetoreception in multicellular organisms [14]. In this investigation, for the first time, BMN is considered as a functional material of a wide range of applications.

In this paper, the meningitis - infection of the brain is considered. The main causative agents of meningitis are Streptococcus pneumoniae, Neisseria meningitidis, Haemophilus influenzae type $b$, Listeria monocytogenes, Pseudomonas aeruginosa and Streptococcus agalactiae [15-18].

The content of magnetic nanocrystals is about $5 \cdot 10^{6}$ per gram in the tissues of the human brain, more than $10^{8}$ per gram in the brain membrane, $50 \mathrm{ng} / \mathrm{g}$ average. About $90 \%$ of the particles have a size of 10-70 nm, and $10 \%$ have a size 90$200 \mathrm{~nm}$. The particles are grouped into clusters of 50 to 100 nanoparticles [4, 19].

Recent advances have shown that artificial nanoparticles are able to get into the brain, overcoming the blood-brain barrier. So if artificial nanoparticles are able to get into the brain they can interact with BMN in brain tissue. This data should be considered as the treatment of pathologies of the brain and during MRI survey especially significant for people in old age.

Extensive use of magnetic resonance in clinical practice and BMN discovery in the tissues and organs of the human body have raised new issues concerning the health risks associated with MR. It was proved by using isothermal residual magnetization and magnetic field changes that the magnetic force associated with the interaction of particles and ferromagnetic MR magnetic fields can be dangerous to sensitive tissue such as the human brain [11].

The aim of the work is to investigate the BMN in the brain as a functional material whose biosynthesis is programmed at the genetic level, both in regions of the human brain [19] and in microorganisms causing pathogens of the brain. The task is to identify potential producers of BMN among the microorganisms of pathogens of the brain and to show that these microorganisms can lead to the additional accumulation of BMN in brain (for example, due to the magnetic dipole interaction of the BMN of these microorganisms with the brain BMN [10]). Therefore, these microorganisms are perspective for use in attenuated form (with reduced virulence) as a contrast agent for magnetic resonance imaging (MRI) [20], as magnetically controlled vectors with natural ferrimagnetism properties for target drug delivery to the brain [21], moreover microorganisms are powerful for the in vivo and in vitro production of magnetic nanoparticles for nanoelectronics [22].

\section{Experimental}

Bioinformatics methods allow to compare a query protein with a specific set of proteins from a database by sequence alignment of amino acid residues. Statistically significant alignments, or matches, between the compared sequences are used for finding homologs, i.e., proteins descending from a common ancestor and having the same function.

The study standard methods used pairwise alignment with a free access program "BLAST" National Center for Biotechnology Information [23]. Two indicators Ident and E-value are considered to estimate the degree of similarity.

Ident $(\%)$ is the number of identical amino acid residues in proteins that is compared with the optimal alignment [24]. Ident value should be greater than $18 \%$ [25]. E-value is a parameter that reflects the statistical significance of alignment reducing the value of which indicates a lower level of rate of coincidence display at amino acid residues of proteins compared. The value of this parameter changes with increasing amounts of information in the database [24]. Today, the recommended threshold E-value, to search for homologous proteins in the NCBI database, should be $<0.05$ [26]. The research takes into account the length of the alignment. To assert that these results are not accidental coincidence length of alignment should be $>100$ amino acid residues.

Comparison of the amino acid sequences of Mam proteins, indispensable in biomineralization BMN Magnetospirillum gryphiswaldense MSR-1 (for which the process of biomineralization BMN is studied genetically in detail [27-29]), is carried out with proteome of Streptococcus pneumoniae, Neisseria meningitidis, Listeria monocytogenes, Pseudomonas aeruginosa and Streptococcus agalactiae. 
Table 1. The results of alignment of amino acid sequences of protein that is essential for biomineralization of magnetite in Magnetospirillum gryphiswaldense MSR-1 and proteins of meningitis pathogens

\begin{tabular}{|c|c|c|c|c|c|c|c|}
\hline \multirow{3}{*}{$\begin{array}{l}\text { The strain of } \\
\text { microorganism }\end{array}$} & \multirow{3}{*}{$\begin{array}{c}\text { Comple- } \\
\text { teness of } \\
\text { genome [23] }\end{array}$} & \multicolumn{6}{|c|}{ E-value /Ident/ Length } \\
\hline & & \multicolumn{6}{|c|}{ Proteins of Magnetospirillum gryphiswaldense MSR-1 } \\
\hline & & MamA & MamB & MamM & MamO & MamE & MamK \\
\hline \multirow{3}{*}{$\begin{array}{l}\text { Streptococcus } \\
\text { pneumoniae } \\
\text { GA41410 }\end{array}$} & \multirow{3}{*}{$\begin{array}{l}25 \% \text { of } \\
\text { genome is } \\
\text { known }\end{array}$} & 0.018 & $5 e-28$ & $6 e-24$ & $7 e-04$ & $2 \mathrm{e}-26$ & 0.062 \\
\hline & & $25 \%$ & $29 \%$ & $24 \%$ & $24 \%$ & $40 \%$ & $\mathbf{4 5} \%$ \\
\hline & & 109 & 262 & 261 & 159 & 174 & 331 \\
\hline \multirow{3}{*}{$\begin{array}{l}\text { Neisseria } \\
\text { meningitidis } \\
\quad \mathrm{Z} 2491\end{array}$} & \multirow{3}{*}{$\begin{array}{l}\text { genome is } \\
\text { completely } \\
\text { sequenced }\end{array}$} & 0.002 & 0.038 & 3.0 & $2 e-10$ & $9 \mathrm{e}-34$ & 0.57 \\
\hline & & $23 \%$ & $34 \%$ & $32 \%$ & $29 \%$ & $43 \%$ & $46 \%$ \\
\hline & & 124 & 149 & 72 & 170 & 161 & 345 \\
\hline \multirow{3}{*}{$\begin{array}{c}\text { Listeria mono- } \\
\text { cytogenes sero- } \\
\text { type } 4 \mathrm{~b} \text { str. } \\
\text { F } 2365\end{array}$} & \multirow{3}{*}{$\begin{array}{l}\text { genome is } \\
\text { completely } \\
\text { sequenced }\end{array}$} & $5 e-08$ & $9 e-36$ & $2 \mathrm{e}-32$ & $3 e-05$ & $1 \mathrm{e}-04$ & $5 e-14$ \\
\hline & & $23 \%$ & $28 \%$ & $32 \%$ & $33 \%$ & $32 \%$ & $27 \%$ \\
\hline & & 107 & 271 & 254 & 246 & 104 & 325 \\
\hline \multirow{3}{*}{$\begin{array}{c}\text { Streptococcus } \\
\text { agalactiae } \\
\text { LMG } 14747\end{array}$} & \multirow{3}{*}{$\begin{array}{l}25 \% \text { of } \\
\text { genome is } \\
\text { known }\end{array}$} & 0.15 & $4 e-27$ & $9 e-23$ & 0.02 & $7 e-26$ & 0.028 \\
\hline & & $25 \%$ & $26 \%$ & $26 \%$ & $26 \%$ & $39 \%$ & $27 \%$ \\
\hline & & 120 & 271 & 264 & 170 & 185 & 103 \\
\hline \multirow{3}{*}{$\begin{array}{c}* \text { Pseudomonas } \\
\text { aeruginosa } \\
\text { M18 }\end{array}$} & \multirow{3}{*}{$\begin{array}{l}25 \% \text { of } \\
\text { genome is } \\
\text { known }\end{array}$} & 0.037 & $6 e-12$ & $2 \mathrm{e}-11$ & $1 \mathrm{e}-07$ & $6 e-34$ & 0.042 \\
\hline & & $32 \%$ & $23 \%$ & $25 \%$ & $24 \%$ & $40 \%$ & $34 \%$ \\
\hline & & 81 & 263 & 281 & 184 & 197 & 95 \\
\hline
\end{tabular}

* - the synthesis of BMN was confirmed experimentally [46]. In Table 1, the function shown in Table 2 do not coincide for proteins with the bold values of E-value and Ident. The functions are not known (hypothetical protein) for the proteins (Table 2) with italics values of E-value and Ident.

\section{Results and discussion}

Living organisms have a genetically programmed ability to synthesize a wide spectrum of minerals and other inorganic substances in a process known under the general name of biomineralization [30-32]. Biosynthesis of BMNs from inorganic iron compounds is of particular interest because of the magnetic properties of BMNs. To date, the genetic control of the synthesis of BMNs has only been studied experimentally in magnetotactic bacteria (MTB) [33-35], where it appears to be a strict regulation of the properties and structural organization of the BMNs.

Proteins of biomineralization of BMN in MTB can be divided into two functional classes: proteins indispensable for the biomineralization process of BMNs, and regulatory proteins that carry out the genetic control of size, shape, and localization of magnetite crystals in MTB. The first class of proteins indispensable for the process of biomineralization of magnetite in- cludes proteins such as MamA, MamB, MamM, MamE, MamO [36-39]. Other proteins of biomineralization of MTB belong to regulatory proteins $[37,40]$. A homologue of the MamK protein, which is responsible for the formation of the chains of BMN [37], is found in humans.

Proteins of biomineralization of BMN in MTB is organized mainly in four clusters of genes in MTB Magnetospirillum gryphiswaldense: mms6, mamAB, mamGFDC, and mamXY encoding all known magnetosome membrane proteins. Magnetosome membrane proteins were named Mam, Mme, Mms, Mtx [41].

The loss of proteins of biomineralization in MTB leads to nonmagnetic phenotype of MTB demonstrating its key role in biogenesis of BMNs [33, 42-44]. Thus, the proteins of the Mam group can be used to synthesize nanoparticles and control their physicochemical properties and morphology. This research opens perspectives in the manufacture of functional materials. 
Table 2. Comparison of the functions of proteins in MTB and proteins in human pathogens

\begin{tabular}{||c|c||}
\hline $\begin{array}{r}\text { Proteins of biomineralization in MTB and their } \\
\text { functions }\end{array}$ & Pathogens proteins and their functions \\
\hline $\begin{array}{c}\text { MamA - contains the TPR domain, which is in- } \\
\text { volved in protein-protein interactions, functions } \\
\text { of chaperones, cell cycle, transcription, transport } \\
\text { of proteins }\end{array}$ & $\begin{array}{r}\text { TPR- is a structural motif. TPR-domain involved } \\
\text { in protein- protein interactions. }\end{array}$ \\
\hline MamB - Transporter of Co, Zn, Cd cations & MMT1 - Transporter of Co, Zn, Cd cations \\
\hline MamM - Transporter of Co, Zn, Cd cations & HamO - Serine protease \\
\hline $\begin{array}{r}\text { MamE - Serine protease. PDZ domain of trypsin- } \\
\text { like serine protease is involved in the response to } \\
\text { heat shock, chaperone function, apoptosis }\end{array}$ & HtrA-Serine protease. \\
\hline \hline
\end{tabular}

As shown in this paper [8, 45], the presence of homologs of Magnetospirillum gryphiswaldense MSR-1: MamA, MamB, MamE, MamO, and MamM proteins is sufficient for the formation of intracellular crystalline BMN in the microorganisms under investigation, and the presence of homologs of the MTB Magnetospirillum gryphiswaldense MSR-1 proteins is required to form intracellular amorphous BMN: MamM, MamB, MamE, MamO.

In alignment MTB Magnetospirillum gryphiswaldense MSR-1 with proteome pathogens, found that Streptococcus pneumoniae, Neisseria meningitidis, Listeria monocytogenes, Pseudomonas aeruginosa and Streptococcus agalactiae are potential producers of BMN (Table 1). Homology of biomineralization proteins and microorganisms pathogens of meningitis and MTB confirmed the same functions (Table 2). Lack of homolog of protein MamA in Streptococcus agalactiae and Pseudomonas aeruginosa indicates that these organisms may be potential producers of amorphous intracellular BMN. This ability to synthesize amorphous intracellular BMN in Pseudomonas aeruginosa confirms experimentally [46].

Neisseria meningitidis and Streptococcus pneumonia are potential producers of crystal BMN (Table 1). Moreover, availability of protein homologues MamK in these organisms indicates that the BMN are associated with the cell membrane [45]. Despite the fact that the E-value of the protein homolog MamK in Neisseria meningitides is greater than 0.05 the function of these proteins are the same. Thus it can be argued that they are homologous [25]. Lack of protein homolog to MamA in Streptococcus agalactiae could be associated with the fact that the genome of the microorganism is not fully sequenced.

\section{Conclusions}

Alignment of proteins amino acid sequences of magnetotactic bacteria Magnetospirillum gryphiswaldense MSR-1 and proteins of microorganisms pathogens of meningitis are conducted using comparative genomics methods. It is shown that Streptococcus pneumoniae, Neisseria meningitidis, Streptococcus agalactiae, Pseudomonas aeruginosa and Listeria monocytogenes are potential producers of BMN. Results of this research open new possibilities for therapy and treatment of bacterial meningitis in adults and children. In addition, these microorganisms can attract a particular interest for the manufacture of magnetic nanoparticles as functional materials of wide range of applications.

Acknowledgements. This project has received funding from the European Union's Horizon 2020 Research and Innovation Programme under Marie Sklodowska-Curie grant agreement No. 644348 (MagIC).

\section{References}

1. P.P.Grassi-Schultheiss, F.Heller, J.Dobson, Biometals, 10, 351 (1997).

2. J.L.Kirschvink, J.Exp.Biol., 92, 333 (1981).

3. R.R.Baker, Nature, 301, 78 (1983).

4. J.L.Kirschvink, A.Kobayashi-Kirschvink, B.J.Woodford, P.Natl.Acad.Sci.USA, $\mathbf{8 9}$, 7683 (1992).

5. A.Kobayashi, N.Yamamoto, J.Kirschvink, J. Japan Soc. Powder and Powder Metallurgy, 44, 94 (1997).

6. F.Brem, A.M.Hirt, M.Winklhofer et al., J.R. Soc. Interface, 3,833 (2006).

7. J.Collingwood, J.Dobson, J.Alzheimers Dis., 10, 215 (2006).

8. T.A.Alexeeva, S.V.Gorobets, O.Yu.Gorobets et al., Med. Perspect., 1 (2014)

9. D.Hautot, Q.A.Pankhurst, N.Khan et al., $P$. Roy. Soc. Lond. B. Bio., 70, 62 (2003). 
10. S.V.Gorobets, O.Yu.Gorobets, Yu.M.Chyzh et al., Biophysics, 58, 379 (2013).

11. O.Strbak, P.Kopcansky, I.Frollo, Meas.Sci. Rew., 3, 85 (2011).

12. Kh.A.Lovenstam, D.L.Kirshvink, S.K.Banerdzhi, Biogennyj Magnetit i Magnitoretseptsiya: Novoe o biomagnetizme, Mir, Moscow (1989) [in Russian].

13. Y.Lei, Z.Shuang, C.Peng et al., Microbiol. Res., 167, 507 (2012).

14. T.Ritz, P.Thalau, J.B.Phillips et al., Nature, 429, 177 (2004).

15. M.C.Thigpen, C.G.Whitney, N.E.Messonnier, New. Engl.J.Med., 364, 2016 (2011).

16. C.O.Andersen, Dan.Med.Bull., 3, 189 (2007).

17. D.S.Stephens, B.Greenwood, P.Brandtzaeg, Lancet, 9580, 2196 (2007).

18. C.R.Huang, C.H.Lu, Y.C.Chuang et al., Jpn. J.Infect. Dis., 60, 397 (2007).

19. I.Y.Iskusnykh, T.N.Popova, Biomeditsinskaya Khimiya, 5, 530 (2010).

20. C.Felton et al., Drug. Metab.Rev., 46, 142 (2014).

21. O.Felfoul et al., Nature Nanotechnology, 11, 941 (2016).

22. I.Yamashita, K.Iwahori, S.Kumagai, Biochim. Biophys. Acta., 8, 846 (2010).

23. http: //blast.ncbi.nlm. nih.gov.

24. W.Li, F.Pio, K.Pawlowski et al., Bioinformatics, 16, 1105 (2000).

25. A.Lesk, Introduction to Bioinformatics, Oxford University Press (2002).

26. http://dpdb.uab.es/dpdb/help_blast.asp

27. S.Ullrich, M.Kube, S.Schubbe et al., J.Bacteriol., 187, 7176 (2005)

28. S.Schubbe, C.Wurdemann, J.Peplies et al., Appl.Environ. Microbiol., 72, 5757 (2006).

29. A.Lohße, S.Ullrich, E.Katzmann et al., PLoS One, 6, e25561 (2011).
30. F.C.Meldrum, H.Colfen, Chem. Rev., 108, 4332 (2008).

31. H.Eherlich, Acta Biomaterialia, 10, 3183 (2014).

32. S.Mann, Biomineralization; Principles and Concepts in Bioorganic Materials Chemistry, Oxford University Press, New York (2001).

33. M.Richter, M.Kube, D.A.Bazylinski, J.Bacteriol., 189, 4899 (2007).

34. A.Fernanda, E.C.Mauricio, F.N.Marisa, The ISME J., 5, 1634 (2011).

35. A.Komeili, FEMS Microbiol.Rev., 36, 232 (2012).

36. S.V.Gorobets, O.Yu.Gorobets, K.O.Butenko, Res. Bull. NTUU "KPI", 3, 23 (2015).

37. O.Yu.Gorobets, S.V.Gorobets, Yu.I.Gorobets, in: Dekker Encyclopedia of Nanoscience and Nanotechnology, 3rd Edition. CRC Press, Florida (2014).

38. A.Komeili, H.Vali, T.J.Beveridge, P.Natl. Acad.Sci.USA, 101, 3839 (2004).

39. D.Murat, A.Quinlan, H.Vali et al., P.Natl. Acad.Sci.USA, 107, 5593 (2010).

40. S.Ullrich, M.Kube, S.Schubbe et al., J.Bacteriol., 187, 7176 (2005).

41. D.Faivre, T.U.Godec, Angew.Chem.Int.Edit. 54, 4728 (2015).

42. D.Murat, A.Quinlan, H.Vali et al., P.Natl. Acad.Sci.USA, 107, 5593 (2010).

43. N.Zeytuni, E.Ozyamak, K.Ben-Harush et al., P. Natl.Acad.Sci.USA, 108, 480 (2011).

44. A.Scheffel, A.Gardes, K.Grunberg et al., $J$. Bacteriol., 190, 377 (2008).

45. O.Yu.Gorobets, S.V.Gorobets, L.V.Sorokina, Functional Materials, 4, 427 (2014).

46. M.Vainshtein, N.Suzina, E.Kudryashova et al., Biol. Cell, 94, 29 (2002). 